\title{
Comparative Analysis of the Property Negotiation Outcome Between Professional Estate Agents and Non-Professional in Akure
}

\author{
Rasidat. Adejoke OLADAPO Ibrahim Olaolo EGUNLETI \\ Department of Estate Management, Federal University of Technology, Akure, Nigeria
}

\begin{abstract}
The paper compares the already established characteristics of the property market negotiator between professional property negotiators (agents/mangers) and non-professional property negotiators to property transactions in order to assess significant difference in their negotiation outcome (final price) from their Principals viewpoints. The target populations in the study were the land and real property owners in the three selected low, medium and high residential densities of Akure city, Nigeria. Their sample size were proportionately selected from their varying sampling frame and stratified random sampling adopted led to identification of distinct types of the residential properties in each densities. Structured close-ended questionnaire was administered on these owners to elicit their perception on the characteristics of their property negotiators at the point of purchase of land or letting of the residences and the negation outcomes. Data analysis was both descriptive and inferential statistics of mean scores with Kruskal Wallis Test and independent sample ttest respectively. Findings showed little significant differences in the ranking for both professional and nonprofessional negotiators characteristics among the respondents and there were slight differences in the land/property values negotiated by both negotiators. However there was sparse information about the estimation of the initial value/price among these negotiators as most asking/initial value has been found to be dictated or influenced by initial property owners/vendors. Despite the intrinsic nature of real property, the expectation is that the fundamental theory of price determination should be displayed in every transaction. The paper recommends that all market participants must be at the same pace of knowledge about previous and prevailing market prices/values to promote mutual and balanced negotiation outcome; otherwise there must be public regulation of market prices/values to increase suboptimal and reduce hyper-optimal outcomes.
\end{abstract}

Keywords: Asking/Initial Price, Negotiation Outcome, Negotiators' Characteristics, Professionals and NonProfessionals, Residential Property Market,

DOI: $10.7176 / \mathrm{JESD} / 10-2-03$

\subsection{INTRODUCTION}

Real property assets are unique and the price cannot be set as the price would be set for a fungible commodity traded in a market in which pricing information is readily available but need negotiation process in its market (Black, 1997). Negotiation is noted as a process that brings two or more parties together in order to accomplish mutually beneficial outcomes, while meeting individual goals (Swaidan, 2007). In addition to this, Iroham, Oloyede and Akinjare (2011) defined negotiation as a process of dialogue intends to produce an agreement upon course of action, for individual on collective advantage, or to craft outcomes to satisfy various interests, real property transactions thus require negotiation for parties' benefits. However, Chongming (2003) noted that negotiation process involved preparatory, exploratory, bidding bargaining, settling and evaluation, ratification and dissemination of product.

In line with this, each of the market negotiators skills and techniques play a part in arriving at final price which often differ or varied or non-existing at times. Yet, these skills and techniques or lack of them reflect in the final outcome. Earlier, Neil and Kevin, (1995) had categorized negotiation into two essential paradigms which are position based and interest based negotiation. Position-based negotiation is where both parties focus on the actual item being negotiated about and where parties see each other as enemy to overcome. In this, each party tends to be self-serving in an attempt to seek victory over the other. While interest based negotiation is where both parties depend on each other to achieve a common goal or objectives. In interest based negotiation the objective is to reach mutually acceptable outcome which is beneficial to both parties while the other could be ruinous and its outcome being suboptimal to weaker party. In other words, the extent to fairness prevail depend opun both parties knowledge about the market.

Estate agents without prejudice to what they are being called anywhere around the globe are trained and skilled in the determination of the market worth of both landed and developed land and are further involved in various property transactions where negotiations to arrive at an agreed price prevails. As the agents role is to act on behalf of the principals that could be varied, but most often for property owners, he must be careful not to allow undue influence to prevail against the third party that is without agent. either in sale or letting transaction. The estate agent prominent role as it regards bringing two separate parties together should have what it takes to 
build confidence in them. This would invariably amongst others reduce if not totally eliminate dual-loyalty conflict agents' face from principals (Kurtzberg, Dunn-Jensen \& Matsibekke,2005). .It could be arguable then that this situation could expose the agent to various forms of influence by these principals so as to attain their whims as has been established in real estate valuation process (Amidu and Aluko, 2007) To purchase the land at a lesser price, negotiations must take place (Charles, 2004).

However there are other categories of agents / negotiator in the market who are called by different names such as mediators, brief-case agents and quasi-professinals (urban planners, land surveyors, quantity surveyors, lawyers architects and other allied professionals that the present economic condition have turned to selling and letting of real properties. Their level of knowledge and skills in property transaction is limited or non- exiting yet much property pass through them to the end users-buyers and renters: land negotiations usually serve as a means to settle buyer-seller interactions concerning land price, date of delivery, and service contracts (Sabine, Markus and Uta, 2009)

Ack and Diaz (1996) argue that due to limited human information processing capacity, potential homebuyers often use the asking value on a home as a shortcut to arrive at negotiated value. Most often, asking value is the ceiling price for the negotiations between sellers and buyers on seller's side, while negotiated value represent negotiators' price targets and thus constitute the best settlement a buyer or a seller can expect to achieve (Zetik\&Stuhlmacher, 2002). Then this depend on the negotiator (buyer) skill.

Furthermore, McGinn and Keros(2003) were of the view that a process argument underlies the assumption that quality representative will lead to greater success, and that parties who share enough information to understand one another's interests are more likely to negotiate better than parties who either do not share information or share information differently. Bazerman, and Carroll (1990) attest that concrete agreements result when parties communicate information regarding their own interests and attend to the information the other party provides. Parties in equal power relationships are motivated to understand each other since they recognize that their own interests can be met only if the other party's interests are met too (Rubin, Pruitt and Kim 1994). This is not often the case in some transactions.

In the process of biding for the purchase of land, most often information are not circulated to all parties involved in the execution of the biding which thereby affect the offer. Muhlebach(2005) viewed that the outcomes in the property market are set on an individual transaction basis by negotiators whose motives, talent, and aspirations are usually conflicting. This usually ends up in an agreement that is preconceived at the same time as a "win-win situation" by parties involved.

Over the past two decades now, the volume of land transactions especially on private land in Akure city has been enormous. This has led to spontaneous expansion of land use at virtually all the urban fringe areas of the city. There is therefore need to identify the characteristics of property negotiators and investigate the level of difference of negotiation outcomes between professional and non-professional negotiators in other to determine their fairness in the process. The subsequent sections of the paper is thus arranged into literature review, materials and methods, results, discussions conclusion and recommendations

\subsection{LITERATURE REVIEW}

\subsection{Negotiation and Characteristics of the Property Negotiators}

Negotiation is a process that brings two or more parties together in order to accomplish mutually beneficial outcomes, while meeting individual goals (Swaiodan, 2007). In addition to this Iroham et al (2011) defined negotiation as a process of dialogue intends to produce an agreement upon course of action, for individual or collective advantage, or to craft outcomes to satisfy various interests. Negotiation is an important mechanism to achieve coordination in exchanges within business markets (Atkin and Rinehart, 2006;). While also viewed as communication process where you attempt to influence someone to give you what you need or want in exchange for something you have that they need or want (Neil and Kevin, 1995).

Apart from this, conventional wisdom has long maintained that some people are good negotiators and others are not (Thompson 2005,) and that successful negotiation can be attributed primarily to natural skill or talent. Neil and Kevin (1995) argue that from the standpoint, a good negotiator is a very skilful communicator, a person who has developed their interpersonal skills to the point where reflective listening, assertion, interest-base questioning, and facilitation are second nature. He went further to describe them as one who have the ability to recognize that both sides are under pressure, and have the desire to negotiate solutions that are mutually beneficial. They are willing to take the time to prepare. They are flexible and are dedicated to using and developing new skills and new behaviour. As with all behaviour change, they realize that a necessary ingredient to acquire more sophisticated negotiation behaviour is the willingness to be open to learning and commitment to practice.

Peter and Jane (2005) identify four most important behavioural skills of great Negotiators, as one; having high aspirations; realizing all power is relative; having good research and planning skills; and using sound strategies and tactics. However, Laurence and Priyan (2015) added to this characteristics if successful 
negotiation is to be achieved. These include individual motivation, cognitive capability, team commitment, openmindedness and interpersonal competency. These characteristics are combined together in the empirical analysis of the Pricncipals considered attributes of their negotiators. The skillful communicator traits refers to ability to impart information well, good listeners by paying attention to every details, high aspiration linked with fervency in ensuring performance, team commitment through sincerity of position; open mindedness by willing to consider new ideas; interpersonal competency despite multiplicity of interest groups; cognitive capacity by being intellectually sound; individual motivation through willingness of action in behaviour. Good research and planning skill by being dynamic; interest base questioning and information power resulting into publicly display of current market data

\subsection{Negotiation Outcome Between Professional And Non-Professional Negotiator.}

Real estate market is usually characterized as inefficient and imperfect market relative to the financial markets. The market consists of real estate professionals and non-professionals mostly acting on behalf of principal in relation to sales or letting of their properties. In the work of Bazerman et al, (1992) using a third party as a mediator and an estate agent (professional) as negotiator in arriving at a market outcome, varying outcome resulted. The third party produced little effect on settlement price while the estate agent negotiating process increased the sales price and the probability of a deadlock on the settlement of price is high. The study further observed that the use of an agent is expected to increase the sales price of the housing unit, since the seller will have to pay the agent's fee out of his surplus, while sometimes the agent add up to the price stated by the seller. A mutually beneficial outcome seems to be prevented in most land market transaction.

Furthermore, the conflicting interest between principals' and the intermediary role played by most professional negotiators during transaction period could prone the latter to influence from these principals' as evident in valuation. While outcomes in the property market are set on an individual transaction basis by negotiators whose motives, talent, and aspirations are usually conflicting (Iroham, et al., 2011). Where such conflict cannot be resolved, negotiation may not be beneficial to both parties. According to Neale and Bazerman (1992) the greatest performance and potential for improvement in negotiation lies on access to information. This usually ends up in an agreement that is preconceived at the same time as a "win-win situation" by parties involved ((Muhlebach, 2005).

In the work of Bazerman,Curhan, More and Valley (2000) on the impact of information shared with thirdparty real estate agents discovered that settlement prices (market outcome) were higher when buyer reservation prices were shared with pricipal's agents and lowest when agents knew only seller reservation prices. Which indicate that the non-professional real estate agent hide under this abnormality to extort the prospective land purchaser. In lease negotiation, Pfrang and Wittig (2008) showed that brokers' influence on the behaviour of the negotiating partners can contribute to the efficiency of negotiation processes and the perceived contract utility. There was also the identification of mutual concessions and the creation of incentives and additional negotiation subjects as possibilities in improving the attractiveness of a lease contract and also in reaching more beneficial contract provisions. These the authors achieved by modeling a game-theoretical framework that covers the basic mechanisms of lease contract negotiations while making allowance for relevant behavioral aspects.

On the whole, the estate agent who has prominent role to play particularly as it regards bringing two separate parties together should have what it takes to build confidence in them. This would invariably amongst others reduce if not totally eliminate dual-loyalty conflict agents' face from principals (Kurtzberg et al., 2005). One way of eliminating such could be by training and education. Myerscough and Tyler (1991) advocated the need for negotiation education; the case for formal negotiation training, the provision of training for the nonprofessional in real estate business, timing of the training provision, and the effectiveness of various teaching methods for training the non-professional in real estate was outlined.

\subsection{MATERIALS AND METHODS}

The study employed cross-sectional survey research design while the target population comprises of: the practicing Estate Surveyors and Valuers as the professional negotiators and the Land Surveyors lawyers and other land negotiators as the non-professional together with Land Owners, within the low, medium and high density residential neighbourhood in Akure Their sample size were obtained by using the method derived by Yamen (1967) as adopted in Umeokafor (2010) to arrive at 26,( 8,17,20): 45 and land owners on low density residential zones within the urban fringe of 100; medium density zone within the inner suburban of 120 and high density zone within the city core of 180 respectively. The stratified coupled with systematic random samplings were used to select each of these sizes. From their population A structured self- administered questionnaire were later designed and used to obtain relevant data needed for analysis to resolve the objectives of the study. Data collected were analyzed using weighted mean scores, kruskal wallis test and Independent Sample T-Test. In the mean scores, each attributes were rated against a pre-defined 5-point likert scale with 5, 4, 3, 2 and 1 denoting "Strongly Agree, "Agree "Undecided", "Disagreet" and "Strongly Disagree". which assists in assessing their 
significances as well as their rankings. The Kruskal-Wallis test (or H test) was used to compare mean values of more than independent two group/samples., which represented the land owners in the three densities In this test, scores are converted to ranks and the mean for each group is compared. The formula for $\mathrm{H}$ test is stated below:

$H=\frac{12}{n(n+1)} \sum_{j=1}^{k}\left(\frac{R j^{2}}{n j}-3(n+1)\right)$

Where:: $n$ is $n 1+n 2+\ldots+n k$ and; $\mathrm{n}=$ the total sample size; $\mathrm{nj}$ is the sample size in the $\mathrm{j}$ th group; $\mathrm{k}=$ the number of comparison groups; $R i=$ sum of the ranks assigned to niobservations in the $i$ th sample.

\subsection{RESULTS}

Data collected for the study were basically primary data from the occupants of the three residential densities selected (viz High, medium and low density areas); practicing Estate Surveying and Valuation firms (as professional negotiators and other allied professionals (as non-professional negotiators).

\subsection{Socio-Economic Characteristics of Respondents}

Table 1: Socio-Economic and general Characteristics of the Property Owners/Occupants in the Three Densities in Akure

\begin{tabular}{|c|c|c|c|c|c|c|}
\hline \multirow{2}{*}{$\begin{array}{l}\text { Socio-Economic and general } \\
\text { Characteristics of the Property } \\
\text { Owners/Occupants }\end{array}$} & \multicolumn{2}{|c|}{ High Density } & \multicolumn{2}{|c|}{ Medium Density } & \multicolumn{2}{|c|}{ Low Density } \\
\hline & Frequency & Percent & Frequency & Percent & Frequency & Percent \\
\hline \multicolumn{7}{|l|}{ Respondents Age } \\
\hline Below 30 Years & 8 & 4.9 & 6 & 5.4 & 6 & 6.4 \\
\hline $31-40$ Years & 43 & 26.4 & 27 & 24.1 & 26 & 27.7 \\
\hline $41-50$ Years & 56 & 34.4 & 37 & 33.0 & 34 & 36.2 \\
\hline $51-60$ Years & 40 & 24.5 & 30 & 26.8 & 20 & 21.3 \\
\hline 61 Years and above & 16 & 9.8 & 12 & 10.7 & 8 & 8.5 \\
\hline Total & 163 & 100.0 & 112 & 100.0 & 94 & 100.0 \\
\hline \multicolumn{7}{|l|}{ Gender } \\
\hline Male & 121 & 74.2 & 85 & 75.9 & 70 & 74.5 \\
\hline Female & 42 & 25.8 & 27 & 24.1 & 24 & 25.5 \\
\hline Total & 163 & 100.0 & 112 & 100.0 & 94 & 100.0 \\
\hline \multicolumn{7}{|l|}{ Educational Qualification } \\
\hline OND & 27 & 16.6 & 15 & 13.4 & 18 & 19.1 \\
\hline HND & 40 & 24.5 & 24 & 21.4 & 28 & 29.8 \\
\hline B. Sc & 48 & 29.4 & 37 & 33.0 & 24 & 25.5 \\
\hline M. Sc & 32 & 19.6 & 24 & 21.4 & 16 & 17.0 \\
\hline $\mathrm{PhD}$ & 16 & 9.8 & 12 & 10.7 & 8 & 8.5 \\
\hline Total & 163 & 100.0 & 112 & 100.0 & 94 & 100.0 \\
\hline \multicolumn{7}{|l|}{ Occupation } \\
\hline Civil Servants & 48 & 29.4 & 35 & 31.3 & 24 & 25.5 \\
\hline Self-Employed & 32 & 19.6 & 24 & 21.4 & 16 & 17.0 \\
\hline Private Company & 74 & 45.4 & 48 & 42.9 & 48 & 51.1 \\
\hline Retired Personnel & 9 & 5.5 & 5 & 4.5 & 6 & 6.4 \\
\hline Total & 163 & 100.0 & 112 & 100.0 & 94 & 100.0 \\
\hline \multicolumn{7}{|l|}{ Marital Status } \\
\hline Single & 18 & 11.0 & 10 & 8.9 & 12 & 12.8 \\
\hline Married & 113 & 69.3 & 78 & 69.6 & 66 & 70.2 \\
\hline Divorced & 24 & 14.7 & 18 & 16.1 & 12 & 12.8 \\
\hline Widow & 8 & 4.9 & 6 & 5.4 & 4 & 4.3 \\
\hline Total & 163 & 100.0 & 112 & 100.0 & 94 & 100.0 \\
\hline \multicolumn{7}{|l|}{ Monthly Income } \\
\hline Less than $\# 30,000$ & 9 & 5.5 & 5 & 4.5 & 6 & 6.4 \\
\hline$\# 30,001-\# 50,000$ & 42 & 25.8 & 27 & 24.1 & 28 & 29.8 \\
\hline$\# 50,001-\# 70,000$ & 56 & 34.4 & 36 & 32.1 & 32 & 34.0 \\
\hline$\# 70,001$ - \#90,000 & 56 & 34.4 & 44 & 39.3 & 28 & 29.8 \\
\hline Total & 163 & 100.0 & 112 & 100.0 & 94 & 100.0 \\
\hline \multicolumn{7}{|l|}{ Plot Size } \\
\hline $15 \mathrm{~m} \times 30 \mathrm{~m}$ & 131 & 80.4 & 88 & 78.6 & 78 & 83.0 \\
\hline $18 \mathrm{~m} \times 36 \mathrm{~m}$ & 16 & 9.8 & 14 & 12.5 & 8 & 8.5 \\
\hline
\end{tabular}




\begin{tabular}{lcccccc}
\hline $36 \mathrm{~m} \times 72 \mathrm{~m}$ & 8 & 4.9 & 5 & 4.5 & 4 & 4.3 \\
$30 \mathrm{~m} \times 30 \mathrm{~m}$ & 8 & 4.9 & 5 & 4.5 & 4 & 4.3 \\
Total & $\mathbf{1 6 3}$ & $\mathbf{1 0 0 . 0}$ & $\mathbf{1 1 2}$ & $\mathbf{1 0 0 . 0}$ & $\mathbf{9 4}$ & $\mathbf{1 0 0 . 0}$ \\
\hline
\end{tabular}

Source: field survey, 2017

Table 1 analyses the socio-economic and general characteristics of the property owners/ occupants of Akure based on the three densities viz High density, medium and low density areas. Various characteristics such as the age, gender, educational qualification, occupation, marital status, monthly income amongst other have been examined to justify the relative impact of the socio-economic characteristics with respect to their opinions on the research.

As shown in table 6, the result revealed that majority of the respondents across the three housing densities are within the age bracket of $41-50$ years representing $34.4 \%, 33 \%$ and $36.2 \%$ within the high, medium and low density areas respectively. This is closely followed by the respondents within the age bracket of 31-40 years representing $26.4 \%, 24.1 \%$ and $27.7 \%$ in the high, medium and low density areas. The age distribution of the respondents thus showed that the sampled respondents are old enough to guarantee reliable data for further analysis about the study. The gender distribution showed that most of the respondents are males representing $74.2 \%, 75.9 \%$ and $74.5 \%$ as the property owners/occupants in the high, medium and low density areas respectively. The respondent's educational qualification showed that majority of the respondents in the high and medium density areas are B.Sc holders representing $29.4 \%$ and $33 \%$ respectively. The occupants of the low density areas are mostly HND holders representing 29.8\%. HND holders in the high and medium density areas represent $24.5 \%$ and $21.4 \%$. The educational qualification of the respondents implied that they are well learned and educated enough to understand the subject matter upon which their opinion are sought.

The occupation of the respondents also revealed that most of the respondents work in private companies $45.4 \%, 42.9 \%$ and $51.1 \%$ as opined by the occupants in the High, medium and low density areas respectively. The civil servants represents $29.4 \%, 31.3 \%$ and $25.5 \%$ respectively while the self-employed represents $19.6 \%$, $21.4 \%$ and $17.0 \%$ as opined by the occupants in the high, medium and low density areas. The occupation of the respondents when related to the marital status of the respondents revealed that most of the respondents are married representing $69.3 \%, 69.6 \%$ and $70.2 \%$ as opined by the occupants/ respondents in the high, medium and low density areas. The findings of the occupation and marital status of the respondents further ascertains the maturity of the respondents and thus their opinions relating to having knowledge of the market negotiators on property ownership and possession be adequately relied upon.

The monthly income of the respondents revealed that most of the respondents in the high density areas collect between $\# 50,000$ and above which represents $34.4 \%$ respectively. From the perspectives of the occupants in the medium densities, majority of respondents earn \#70,000 and above representing 39.3\% and those within $\# 50,001$ - \#70,000 represents $32.1 \%$. The plot size of the property being majorly occupied by the respondents across the target areas revealed that $15 \mathrm{~m} \mathrm{x} 30 \mathrm{~m}$ is the major plot size in the areas representing $80.4 \%, 78.6 \%$ and $83.0 \%$ as opined by the respondents in the high, medium and low density areas.

Table 2: Socio-Economic and general Characteristics of the Professional and the Non-Professional Property Negotiators in Akure

\begin{tabular}{|c|c|c|c|c|}
\hline \multirow[t]{2}{*}{ Socio-Economic and general Characteristics } & \multicolumn{2}{|c|}{$\begin{array}{c}\text { Professional Property } \\
\text { Negotiator }\end{array}$} & \multicolumn{2}{|c|}{$\begin{array}{cc}\text { Non- } & \text { Professional } \\
\text { Property Negotiators }\end{array}$} \\
\hline & Frequency & Percent & Frequency & Percent \\
\hline \multicolumn{5}{|l|}{ Respondents Position in the Firm } \\
\hline Principal \& Managing Partner & 6 & 27.3 & 14 & 35.9 \\
\hline Partner & 2 & 9.1 & 5 & 12.8 \\
\hline Branch Manager & 2 & 9.1 & 4 & 10.3 \\
\hline Senior Estate Surveyor \& Valuer & 10 & 45.5 & - & - \\
\hline Estate Surveyor and Valuer & 2 & 9.1 & 2 & 5.1 \\
\hline Others & - & - & 14 & 35.9 \\
\hline Total & 22 & 100.0 & 39 & 100.0 \\
\hline \multicolumn{5}{|l|}{ Gender } \\
\hline Male & 16 & 72.7 & 30 & 76.9 \\
\hline Female & 6 & 27.3 & 9 & 23.1 \\
\hline Total & 22 & 100.0 & 39 & 100.0 \\
\hline \multicolumn{5}{|l|}{ Educational Qualification } \\
\hline OND & - & - & - & - \\
\hline HND & 6 & 27.3 & 12 & 30.8 \\
\hline B. Sc & 6 & 27.3 & 13 & 33.3 \\
\hline M. Sc & 8 & 36.4 & 11 & 28.2 \\
\hline
\end{tabular}




\begin{tabular}{|c|c|c|c|c|}
\hline $\mathrm{PhD}$ & 2 & 9.1 & 3 & 7.7 \\
\hline Total & 22 & 100.0 & 39 & 100.0 \\
\hline \multicolumn{5}{|c|}{ Years of professional Practice } \\
\hline $1-5$ Years & 2 & 9.1 & 2 & 5.1 \\
\hline $6-10$ Years & 11 & 50.0 & 19 & 48.7 \\
\hline $11-15$ Years & 5 & 22.7 & 8 & 20.5 \\
\hline 16 Years and above & 4 & 18.2 & 10 & 25.6 \\
\hline Total & 22 & 100.0 & 39 & 100.0 \\
\hline \multicolumn{5}{|c|}{ Professional Qualification } \\
\hline Graduate / Probationers & 3 & 13.6 & 9 & 23.1 \\
\hline Associates & 15 & 68.2 & 26 & 66.7 \\
\hline Fellows & 2 & 9.1 & 2 & 5.1 \\
\hline Others & 2 & 9.1 & 2 & 5.1 \\
\hline Total & 22 & 100.0 & 39 & 100.0 \\
\hline \multicolumn{5}{|l|}{ Age of the Firm } \\
\hline $1-10$ Years & 11 & 50.0 & 15 & 38.5 \\
\hline $11-20$ Years & 10 & 45.5 & 21 & 53.8 \\
\hline $21-30$ Years & 1 & 4.5 & 3 & 7.7 \\
\hline Total & 22 & 100.0 & 39 & 100.0 \\
\hline \multicolumn{5}{|c|}{ Opinion on Having Sold land in Akure before } \\
\hline Yes & 22 & 100.0 & 39 & 100.0 \\
\hline No & - & - & - & - \\
\hline Total & 22 & 100.0 & 39 & 100.0 \\
\hline
\end{tabular}

Source: field survey, 2017

Table 2 further examined the socio-economic and general characteristics of practicing Estate Surveying and Valuation firms and property negotiators in Akure. As revealed during the course of the research, majority of the respondents in the Estate Surveying and Valuation firms are Senior Estate Surveyors and Valuers representing $45.5 \%$ while the property negotiators on the other hand consist of various other allied professions which have been grouped as others and representing 35.9\%. The respondents position in the firm as shown in the table 7 above showed that the respondents are well positioned and thus their opinions relating to the effect of property negotiators on property values can be adequately relied on.

The gender distribution of the respondents showed that most of the respondents are males representing $72.7 \%$ and $76.9 \%$ as opined by the practicing Estate Surveying and Valuation firms and property negotiators respectively. Females on the other hand connote $27.3 \%$ and $23.1 \%$ respectively. The gender distribution of the respondents showed that a large dominance of males in the real estate and property market requiring continuous involvement of female surveyors and property market players.

The educational qualification of the respondents further showed that most of the respondents in the Practicing Estate Surveying and Valuation firms are majorly Master degree holders representing 36.4\%. B. Sc and HND holders represent $27.3 \%$ respectively. For the property negotiators on the other hand, the study revealed that most of the property negotiators are B.Sc holders representing $33.3 \%$ while HND and master degree holders represents $30.8 \%$ and $28.2 \%$ respectively. The educational qualification of the respondent also showed that majority of the respondents are well learned and educated and thus, their opinion regarding the research can be adequately relied on.

The years of professional practice of the respondents also showed that majority of the respondents have between 6-10 years of professional experience representing 50.0\% and $48.7 \%$ as respectively opined by the practicing Estate Surveying and Valuation firms and the property negotiators respectively. $22.7 \%$ and $18.2 \%$ of the practicing Estate Surveying and Valuation firms have professional years of experience spanning 11 years and above. The years of professional practice and the professional qualification of the respondents revealed that majority of the respondents are Associates of their respective professions representing $68.2 \%$ and $66.7 \%$ as opined by the practicing Estate Surveying and Valuation firms and property negotiators respectively. The years of professional practice and professional qualification further buttresses the reliability of the opinions and response received from the targeted population.

The age of the firm and the opinions of the respondents on having been involved in the sale of land in Akure revealed that a large proportion of the firms aged between 1-20 years and have all been involved in the sale and purchase of a landed property in Akure before.

Conclusively, the reviewed characteristics of the respondents thus showed that theorespondents are well placed, positioned with good educational and professional experience. Therefore their opinions on the effect of market negotiators of property values can be adequately relied on. 


\subsection{The Characteristics of Property Negotiators in the Land Market within Akure}

The perceptions of the land and property owners were sought on the already established characteristics of the property negotiators from available literature reviewed. The believed is that property owners consult them more often than the potential users in negotiations and these owners could assess them objectively than allowing the negotiators to assess their perceived attributes. Hence, owners' opinions were carefully analysed and presented using weighted mean score and Kruskawalis test respectively. The results are as presented in the tables below:

Table 3: Land and Property Owners' Opinion on the Characteristics of Property Negotiators in the Market in Akure.

\begin{tabular}{|c|c|c|c|c|c|c|c|c|c|c|c|c|c|}
\hline \multirow[t]{2}{*}{$\begin{array}{l}\text { Respondents } \\
\text { Groupings }\end{array}$} & \multirow{2}{*}{$\begin{array}{l}\text { Characteristics of } \\
\text { Property } \\
\text { Negotiators }\end{array}$} & \multicolumn{3}{|c|}{$\begin{array}{c}\text { Occupants of High } \\
\text { Density }\end{array}$} & \multicolumn{3}{|c|}{$\begin{array}{c}\text { Occupants of Medium } \\
\text { Density }\end{array}$} & \multicolumn{3}{|c|}{$\begin{array}{c}\text { Occupants of Low } \\
\text { Density }\end{array}$} & \multicolumn{3}{|c|}{ Kruskawalis Test } \\
\hline & & Mean & $\begin{array}{l}\text { Std. } \\
\text { Dev }\end{array}$ & Rank & Mean & $\begin{array}{l}\text { Std. } \\
\text { Dev }\end{array}$ & Rank & Mean & $\begin{array}{l}\text { Std. } \\
\text { Dev }\end{array}$ & Rank & $\begin{array}{c}\text { Chi } \\
\text { Square }\end{array}$ & Df & Asymp.sig \\
\hline \multirow{11}{*}{$\begin{array}{l}\text { Professional } \\
\text { Negotiators }\end{array}$} & $\begin{array}{l}\text { Skilful } \\
\text { Communicator }\end{array}$ & 4.6564 & .47636 & $6^{\text {th }}$ & 4.6696 & .47246 & $6^{\text {th }}$ & 4.6596 & .47639 & $6^{\text {th }}$ & .053 & 2 & .974 \\
\hline & Good Listener & 4.2147 & .75148 & $10^{\text {th }}$ & 4.1964 & .73324 & $10^{\text {th }}$ & 4.2766 & .76768 & $10^{\text {th }}$ & .820 & 2 & .664 \\
\hline & High Aspiration & 4.5337 & .60126 & $8^{\text {th }}$ & 4.5536 & .58262 & $8^{\text {th }}$ & 4.5319 & .61700 & $9^{\text {th }}$ & .047 & 2 & .977 \\
\hline & Team Commitment & 4.7546 & .43165 & $5^{\text {th }}$ & 4.7679 & .42410 & $5^{\text {th }}$ & 4.7447 & .43838 & $5^{\text {th }}$ & .152 & 2 & .927 \\
\hline & Open Mindedness & 4.5951 & .49239 & $7^{\text {th }}$ & 4.6071 & .49058 & $7^{\text {th }}$ & 4.6170 & .48872 & $7^{\text {th }}$ & .125 & 2 & .939 \\
\hline & $\begin{array}{l}\text { Interpersonal } \\
\text { Competency }\end{array}$ & 4.8957 & .30658 & $2^{\text {nd }}$ & 4.9018 & .29894 & $2^{\text {nd }}$ & 4.8936 & .30998 & $1^{\text {st }}$ & .042 & 2 & .979 \\
\hline & Cognitive Capacity & 4.8528 & .35544 & $4^{\text {th }}$ & 4.8393 & .36892 & $4^{\text {th }}$ & 4.8723 & .33550 & $4^{\text {th }}$ & .448 & 2 & .799 \\
\hline & $\begin{array}{l}\text { Individual } \\
\text { Motivation }\end{array}$ & 4.9018 & .29845 & $1^{\text {st }}$ & 4.9107 & .28644 & $1^{\text {st }}$ & 4.8936 & .30998 & $1^{\text {st }}$ & .170 & 2 & .918 \\
\hline & $\begin{array}{l}\text { Good research and } \\
\text { Planning Skill }\end{array}$ & 4.5092 & .59180 & $9^{\text {th }}$ & 4.4643 & .59923 & $9^{\text {th }}$ & 4.5745 & .57715 & $8^{\text {th }}$ & 1.977 & 2 & .372 \\
\hline & $\begin{array}{l}\text { Interest base } \\
\text { questioning }\end{array}$ & 3.9509 & .58588 & $11^{\text {th }}$ & 3.9464 & .61277 & $11^{\text {th }}$ & 3.9574 & .54703 & $11^{\text {th }}$ & .026 & 2 & .987 \\
\hline & Information power & 4.8957 & .30658 & $2^{\text {nd }}$ & 4.8929 & .31068 & $3^{\text {rd }}$ & 4.8936 & .30998 & $1^{\text {st }}$ & .006 & 2 & .997 \\
\hline \multirow{12}{*}{$\begin{array}{l}\text { Non } \\
\text { Professional } \\
\text { Negotiators }\end{array}$} & Skilful & 3.7546 & 1.4703 & $6^{\text {th }}$ & 3.6071 & 1.67309 & $6^{\text {th }}$ & 3.6383 & 1.48723 & $4^{\text {th }}$ & 1.729 & 2 & .421 \\
\hline & Communicator & & & & & & & & & & & & \\
\hline & Good Listener & 3.4663 & 1.3801 & $10^{\text {th }}$ & 3.3304 & 1.58477 & $10^{\text {th }}$ & 3.4468 & 1.05359 & $7^{\text {th }}$ & .732 & 2 & .693 \\
\hline & High Aspiration & 3.6442 & 1.4388 & $9^{\text {th }}$ & 3.5446 & 1.65974 & $9^{\text {th }}$ & 3.5000 & 1.08509 & $6^{\text {th }}$ & 4.887 & 2 & .087 \\
\hline & Team Commitment & 3.7914 & 1.4884 & $5^{\text {th }}$ & 3.6786 & 1.70961 & $5^{\text {th }}$ & 3.5957 & 1.14834 & $5^{\text {th }}$ & 6.977 & 2 & .031 \\
\hline & Open Mindedness & 3.6871 & 1.4338 & $7^{\text {th }}$ & 3.5893 & 1.66335 & $7^{\text {th }}$ & 3.8298 & .97978 & $2^{\text {nd }}$ & 1.710 & 2 & .425 \\
\hline & $\begin{array}{l}\text { Interpersonal } \\
\text { Competency }\end{array}$ & 3.9018 & 1.5365 & $1^{\text {st }}$ & 3.7857 & 1.75750 & $1^{\text {st }}$ & 3.8511 & .99415 & $1^{\text {st }}$ & 16.143 & 2 & .000 \\
\hline & Cognitive Capacity & 3.8957 & 1.5340 & $2^{\text {nd }}$ & 3.7679 & 1.75007 & $4^{\text {th }}$ & 3.8085 & .96472 & $3^{\text {rd }}$ & 18.564 & 2 & .000 \\
\hline & $\begin{array}{l}\text { Individual } \\
\text { Motivation }\end{array}$ & 3.8957 & 1.5340 & $2^{\text {nd }}$ & 3.7768 & 1.75381 & $2^{\text {nd }}$ & 3.2660 & 1.21969 & $10^{\text {th }}$ & 23.298 & 2 & .000 \\
\hline & $\begin{array}{l}\text { Good research and } \\
\text { Planning Skill }\end{array}$ & 3.6626 & 1.4454 & $8^{\text {th }}$ & 3.5625 & 1.66458 & $8^{\text {th }}$ & 3.2872 & 1.25828 & $9^{\text {th }}$ & 6.156 & 2 & .046 \\
\hline & $\begin{array}{l}\text { Interest } \\
\text { questioning }\end{array}$ & 3.2515 & 1.1881 & $11^{\text {th }}$ & 3.0982 & 1.38824 & $11^{\text {th }}$ & 3.1596 & 1.11975 & $11^{\text {th }}$ & .379 & 2 & .827 \\
\hline & Information power & 3.8957 & 1.5340 & $2^{\text {nd }}$ & 3.7768 & 1.75381 & $2^{\text {nd }}$ & 3.4149 & 1.35527 & $8^{\text {th }}$ & 10.826 & 2 & .004 \\
\hline
\end{tabular}

In table 3 the property owners ratings among the three residential densities were proportionately big and uniform. Going by the decision rule of any rating above 4.0000 revealed greater possessions of the characteristics implied that the professional negotiators in the study areas were in tune with the established attributes and were well displayed in both property sales and rental transactions. The Kruskal Wallis Test also showed that there is no significant difference in the rankings of what the property owners perceived that the professional negotiators demonstrated in their property market transactions. In other words, at 0.05 level of significance, the land/ property ownerss of the three (3) sampled residential densities show indifference in the ratings of the established characteristics of professional property negotiators in Akure.

These established (from literature) characteristics of the market negotiators were considered for the nonprofessional property negotiators by the land/property owners as well. In actual fact, all the property owners sampled cannot be commissioning both categories of negotiators for the same transactions, so different categories of owners whose negotiators were not Estate Surveyors and Valuers were also examined during the course of the research. Their opinions were far below owners whose negotiators were professionals at least based on the initial decision rule; as none of their mean scores were up to 4.000 . Incidentally these ratings were lower and uniform among the owners.

The Kruskal Wallis Test on the ratings of the respondents on non-professional negotiators showed that there were no significance differences on their ratings at 0.05 significance levels. However it was observed that there wer keen competition between both the professional and non-professional negotiators suggesting that that aspect of the services of the Estate Surveyors and Valuers are being usurped by allied professionals in the study area.

Although the professional property negotiators have higher mean values than the non-professional property negotiators in the owners' ratings of these characteristics of property negotiators, the property owners and even the third party seems not to identify any difference in their obligations. 
4.4 The Difference in Negotiation Outcome between Professional and Non-Professional Negotiator

The levels of difference in negotiation outcome between professional and non-professional negotiators were also considered during the research. The study also assessed some various types of residential properties and its eventual outcome (value) based on the negotiation between professionals and non-professionals were conducted.

Table 4: Respondents Opinion on the Difference in Negotiation Between Professional and NonProfessional Property Negotiators

\begin{tabular}{lccccc}
$\begin{array}{l}\text { Respondents Opinion } \begin{array}{l}\text { on } \\
\text { Negotiation }\end{array} \\
\text { There is Difference }\end{array}$ & $\begin{array}{c}\text { Difference } \\
\text { in }\end{array}$ & $\begin{array}{c}\text { Professionals } \\
\text { Negotiators }\end{array}$ & $\begin{array}{c}\text { Non -Professionals } \\
\text { Negotiators }\end{array}$ \\
\cline { 2 - 5 } & Frequency & Percent & Frequency & Percent \\
There is no difference & 12 & 54.5 & 27 & 69.2 \\
Total & 10 & 45.5 & 12 & 30.8 \\
\hline
\end{tabular}

The table showed the respondents' opinion on the difference in negotiation between professional and nonprofessional real estate agents as negotiators. The descriptive statistics of frequencies and percentages revealed that there are differences in their market outcome by 55 percents and 69 percents of both negotiation between professional and non-professional real estate agent respectively.

Table 5: Group Statistics For Differences in Mean Market Values of Residential Land and Property Types Based on the Negotiators

\begin{tabular}{llrcrr}
\hline & Negotiator & N & Mean & Std. Dev & Std. Error Mean \\
\hline \multirow{3}{*}{ Land } & Professional Estate Negotiators & 5 & 1818000.0000 & 1116073.47428 & 499123.23128 \\
& Non-Professional Negotiators & 5 & 1732000.0000 & 1113157.67077 & 497819.24430 \\
& & & & & \\
\multirow{2}{*}{ Tenement Buildings } & Professional Estate Negotiators & 5 & 30200.0000 & 8074.65170 & 3611.09402 \\
& Non-Professional Negotiators & 5 & 27000.0000 & 6855.65460 & 3065.94194 \\
& & & & & \\
Block of Flats & Professional Estate Negotiators & 5 & 210000.0000 & 49497.47468 & 22135.94362 \\
& Non-Professional Negotiators & 5 & 224000.0000 & 53197.74431 & 23790.75451 \\
Bungalows & Professional Estate Negotiators & 5 & 218000.0000 & 56745.04384 & 25377.15508 \\
& Non-Professional Negotiators & 5 & 175000.0000 & 95916.63047 & 42895.22118 \\
& & & & & \\
Duplex & Professional Estate Negotiators & 5 & 360000.0000 & 41833.00133 & 18708.28693 \\
& Non-Professional Negotiators & 5 & 376000.0000 & 38470.76812 & 17204.65053 \\
\hline
\end{tabular}

Table 5 shows the group statistics of mean sale values for land and mean rental values of different residential property types based on the two categories of negotiators.. The outcomes of negotiation for undeveloped land as negotiated by professional is \#1,818,000 while the non-professionals negotiated \#1,732,000. For tenement buildings, the mean negotiated rental value is \#30,200 while for non-professional negotiators is $\# 27,000$. The mean rental values for other types residential properties showed differences as well. Iit can generally be seen that the non-professional negotiators have a lower but not too significant difference in the negotiation outcome. This pointed out possibly, an element of desperation to ensure concluded transactions more than the trained/professional negotiators.

The findings of the study are in agreement with the works of Pfrang and Wirrig, (2008) which stated that that brokers' influence on the behaviour of the negotiating partners can contribute to the efficiency of negotiation processes and the perceived contract utility. 
Table 6: Independent Sample T- Test of Difference in the Mean Values of the Residential Properties Negotiation Outcomes between Professional and Non-Professional Negotiators

\begin{tabular}{|c|c|c|c|c|c|c|c|c|c|c|}
\hline & & \multicolumn{2}{|c|}{$\begin{array}{l}\text { Levene's Test } \\
\text { for Equality } \\
\text { of Variances }\end{array}$} & \multicolumn{7}{|c|}{ t-test for Equality of Means } \\
\hline & & \multirow[t]{2}{*}{$\mathbf{F}$} & \multirow[t]{2}{*}{ Sig. } & \multirow[t]{2}{*}{$\mathbf{T}$} & \multirow[t]{2}{*}{ df } & \multirow{2}{*}{$\begin{array}{c}\text { Sig. } \\
(2- \\
\text { tailed) }\end{array}$} & \multirow[t]{2}{*}{$\begin{array}{c}\text { Mean } \\
\text { Difference }\end{array}$} & \multirow[t]{2}{*}{$\begin{array}{l}\text { Std. Error } \\
\text { Difference }\end{array}$} & \multicolumn{2}{|c|}{$\begin{array}{l}95 \% \text { Confidence Interval of } \\
\text { the Difference }\end{array}$} \\
\hline & & & & & & & & & Lower & Upper \\
\hline \multirow{2}{*}{ Land } & $\begin{array}{l}\text { Equal variances } \\
\text { assumed }\end{array}$ & .091 & .771 & .122 & 8 & .906 & 86000.000 & 704945.38796 & $\begin{array}{c}- \\
1539606.97972\end{array}$ & 1711606.97972 \\
\hline & $\begin{array}{l}\text { Equal variances } \\
\text { not assumed }\end{array}$ & & & .122 & 8.000 & .906 & 86000.000 & 704945.38796 & $\begin{array}{c}- \\
1539608.91609\end{array}$ & 1711608.91609 \\
\hline Tenement & $\begin{array}{l}\text { Equal variances } \\
\text { assumed }\end{array}$ & .084 & .779 & .676 & 8 & .518 & 3200.00000 & 4737.08771 & -7723.74385 & 14123.74385 \\
\hline Buildings & $\begin{array}{l}\text { Equal variances } \\
\text { not assumed }\end{array}$ & & & .676 & 7.795 & .519 & 3200.00000 & 4737.08771 & -7773.97732 & 14173.97732 \\
\hline \multirow{2}{*}{$\begin{array}{l}\text { Block of } \\
\text { Flats }\end{array}$} & $\begin{array}{l}\text { Equal variances } \\
\text { assumed }\end{array}$ & .003 & .960 & -.431 & 8 & .678 & -14000.000 & 32496.15362 & -88936.26462 & 60936.26462 \\
\hline & $\begin{array}{l}\text { Equal variances } \\
\text { not assumed }\end{array}$ & & & -.431 & 7.959 & .678 & -14000.000 & 32496.15362 & -89003.87985 & 61003.87985 \\
\hline \multirow{2}{*}{ Bungalows } & $\begin{array}{l}\text { Equal variances } \\
\text { assumed }\end{array}$ & .805 & .396 & .863 & 8 & .413 & 43000.000 & 49839.74318 & -71930.65386 & 157930.65386 \\
\hline & $\begin{array}{l}\text { Equal variances } \\
\text { not assumed }\end{array}$ & & & .863 & 6.494 & .419 & 43000.000 & 49839.74318 & -76737.83152 & 162737.83152 \\
\hline \multirow{2}{*}{ Duplex } & $\begin{array}{l}\text { Equal variances } \\
\text { assumed }\end{array}$ & .056 & .819 & -.630 & 8 & .547 & -16000.000 & 25416.53005 & -74610.62341 & 42610.62341 \\
\hline & $\begin{array}{l}\text { Equal variances } \\
\text { not assumed }\end{array}$ & & & -.630 & 7.944 & .547 & -16000.000 & 25416.53005 & -74681.98633 & 42681.98633 \\
\hline
\end{tabular}

Table 6 shows the result of the Independent Sample T- Test of Difference in the mean values of residential properties based on the negotiators opinions (Professional and Non-Professional Negotiators). The analysis relied on data retrieved from the professional and non-professional negotiators based on some residential property types which were subjected to negotiation by both group of respondents. No statistical difference at 0.05 significant level was seen in the mean values of residential properties by the two negotiators (Professional and Non-Professional Negotiators).

Equally for the mean values of land between the two negotiators (Professional and Non-Professional Negotiators) there was no statistical difference in the opinion of values at 0,05 significant levels $(t(8)=.122, p$ $=0.906)$; and no statistical difference in the mean values of residential properties based on the negotiator (Professional and Non-Professional Negotiators) for duplexes $t(8)=-.630, p=0.547$. The non-professional negotiators rationale of arriving at final outcome is questionable, howver in this era of spot valuation and client influence without any method, the findings could be supporting the augment of Curhan, Elfenbein and Andxu (2006) that most negotiation in an un-informed market are subjective..

There were no information as to owners having a reservation price below which final settlement price can be established neither is there any information about buyers and renters reservation price above which negotiation would have reached a deadlock. This suggest that both the buyer and renters are possibly uninformed about their position in the final negotiation outcome impliedly, outcome have been one sided dictated by the owner and his agents (professional or nono-professionals negotiators) on leave it or take it other will pay basis.. This outcome therefore is no consistent to the submission of Swaidan (2007) that negotiation must achieve mutually beneficial outcomes.

\subsection{CONCLUSION AND RECOMMENDATIONS}

The study examined the differences in the characteristics of both professional and non-professional property market negotiators; and their negotiation outcomes within the residential properties in Akure, a medium sized growing city in Nigeria with a view to determining the Principals' (person that commission them) knowledge of their prevalence in achieving their objectives.. The established characteristics of property negotiators from literature were ascertained by the principals (property owners) to be possessed by both the professional and nonprofessional with little differences in their ratings. These include interpersonal competency; individual motivation and good research and planning skill. The research further revealed that there is no statistical difference at 0.05 significant level in the mean values of residential properties final prices arrived at by the two negotiators (Professional and Non-Professional Negotiators).

There is no doubt that negotiation process often involves two or more parties. In this study it was discovered that both the professional and non-professional negotiators are mostly commissioned by the property owners and most buyers and tenants are not aware that fair outcome can be achieved if two trained or self acclaimed negotiators acted for them and as such final prices are one sided as earlier argued in (Kapoor, 2000). 
Equally, the outcomes by both not having much differences suggest property owners influences on both negotiators (Amidu \& Aluko, 2007) coupled with the fact that negotiators often have access to information that is difficult for the buyers or tenants to obtain and their unwillingness to negotiate below prices that will lower their commission fees (Bazerman et.al., 1992).

Based on these discussions the study recommends that

i. There should be a review of the activities of the Professional Association of the Nigerian Institution of Estate Surveyors and Valuers (NIESV) whose members are the professional negotiators to embark upon strict enforcement of the laws backing their practice on non professional members that are triumphing in property transactions despite their core areas of training, practicing and competence.

ii. There should be new and improved training for the professional negotiators through diverse electronic modules so as to ensure efficiency and technicality that cannot be easily hijacked by nonprofessionals.

iii. There should be adequate sensitization of the public (property owners, buyers and tenants) to patronize professional Estate Surveyors and Valuers who are trained to handle property market negotiations.

iv. All negotiation parties must be at the same pace and be informed about he historical/previous and prevailing market prices in order to promote mutual and balanced negotiation outcome.

v. In the phase of market data secrecy, conservatism and monopolistic behaviour of property owners, there should be public/government regulation of market prices to increase suboptimal and reduce hyper.optimal negotiation outcome to strike a balance

\section{References}

Allred, K. G., (2000). Distinguishing Best And Strategic Practices: A Framework For Managing The Dilemma Between Creating And Claiming Value, Negotiation Journal, 16(4). 45-54

Amidu, A., and Aluko, B. T. (2007). Client influence in residential property valuations: An empirical study.Property Management, 25(5), 447-461.

Anderson, J.C. And Narus, J.A. (2004): Business Market Management. Upper Saddle River.

Ashcroft, S. (2004). Commercial negotiation skills. Industrial and Commercial Training, 36(6), 229-233.

Asika, N. (2004). Research Methodology, Process Approach. Makugamu And Brother Enterprises, Shomolu, Lagos.

Atkin, T. S.And Rinehart L. M. (2006).The Effect Of Negotiation Practices On The Relationships Between Suppliers And Customers.

Bazerman, M. H., Curhan, J. R., More, D. A., \& Valley, K. J. (2000).Negotiation. Annual Review Of Psychology, $51,279-314$.

Black R. \& Diaz, J. (1996), The Use of Information Versus Asking Price in The Real Property Negotiation Process. Journal of Property Research Vol. 13, 43-45.

Black R. T. (1997) Expert Property Negotiators And Pricing Information, Revisited, Journal Of Property Valuation And Investment, 15(3).

Bucchianeri, G. \& Minson, J. (2011), Home Buyer Anchoring or Herding? The Effect of Listing Behaviours on Housing Market Outcome. Working Paper, Univerisity of Pennsylvania.

Cheng, E.A. (2006), Intelligent Agents for E-Market Place; Negotiation With Issues Trade-Offs by Fuzzy Inference Systems, Decision Support Systems 42, 628-638.

Chia-Jung T. And Bazerman H. (2009).A Decision-Making Perspective To Negotiation: A Review Of The Past And A Look Into The Future, Working Paper.

Chongming H. (2003) Modelling Agents Behaviour In Automated Negotiation, Journal Of Knowledge Media Institute, The Open University, Milton Keynes, Mk7 6aa, United Kingdom.

Clayton, J.; Mackinnon, G. And Peng L. (2008). Time Variation Of Liquidity In Private Real Estate Market: An Empirical Investigation. Journal Of Real Estate Research, 30 (2).

Curhan, J.R., Elfenbein, H .Andxu, H. (2006).What Do People Value When They Negotiate; Mapping The Domain Of Subjective Value In Egotiation,Journal Of Personality And Social Psychology, Vol. 91, 493-512.

Datuk A. A. S., Krabben E.,Deemen A.M.A. \&Heijden R.E.C.M. (2015) Negotiation Processes In Land And Property Development: An Experimental Study, Journal Of Property Research, 32(2), 173-191

Eric C. And Michael S. (2015). The Effect Of Listing Price Strategy On Real Estate Negotiations: An Experimental Study.

Gatzlaffd. And Liu P. (2013).List Price Information In The Negotiation Of Commercial Real Estate Transactions: Journal Of Center For Real Estate And Finance.

Herbst, U. And Voeth, M. (2008): Analysis Of Economic And Non-Economic Negotiation Preferences. Proceedings Of The Imp Group Conference 2008, Uppsala, Sweden, September 2008.

Iroham C. O., Oloyede S. A. And Akinjare O. A. (2011) Reference And Anchor Points In Property 
Negotiation: What Influence Has The Estate Valuer?, International Journal Of Marketing Studies. 3 (1)

Iroham, C. O., Oluwunmi, A. O. And Oluwatobi. A. O. (2011) An Exposition On Principals' Influence In Real Estate Negotiation.International Journal Of Marketing Studies. 3 (2).

Kurtzberg, T. C., Dunn-Jensen, L. M., \&Matsibekke, C. L. (2005). Multi-Party Negotiations: Agents, Alliances, And Negotiation Success. International Journal Of Conflict Management, 16(3), Pp. 245-264.

Laurence L. And Priyan K. (2015), The Effect Of Negotiator Characteristics On The Success Of International B2b Negotiations. Proceedings International Marketing Trends Conference, 2015.

Mcginn, K. L. And A. T. Keros. (2003). Improvisation And The Logic Of Exchange In Socially Embedded Trans- Actions. Administrative Science Quarterly 47.

Michael S. (2001): Effects Of Electronic Markets On Negotiation Processes. Journal Of Ibm Research, Zurich Research Laboratory.

Muhlebach, R. (2005). The Seven Deadly Provisions. Journal Of Property Management, 70(3), Pp. 44-6.

Myerscough, J. M., And Tyler, S. B. (1991).Negotiation Education And Training, And The Surveyors. Property Management, 9(2), 130-144.

Neale, M. A., And Bazerman, M. (1992). Negotiating Rationally: The Power And Impact Of The Negotiator's Frame. The Academy Of Management Executive, 6(3).

Neil, K \& Kevin, M. (1995), "Interest Based Negotiations" Retrieved from https://www.maxwell.syr.edu.parcc.cmc.

Pfrang, D. C. and Wittig, S. (2008). Negotiating office lease contracts: From a game-theoretical towards abehavioural view. Journal of European Real Estate Research, 1(1), 88-105

Putnam, L.L. And Roloff, M.E. (1992), Communication And Negotiation, Newbury Park.

Rubin, J. Z., D. G. Pruitt, And S. H. Kim. (1994). Social Conflict: Escalation. Stalemate And Settlement, Boston. Mcgraw-Hill.

Sabine, Markus And Uta (2009), Information Asymmetry In Buyer-Seller Negotiations And Its Impact On Effectiveness, Efficiency And Satisfaction, Competitive Paper Main Session, P 4-7.

Sebenius J. K., 2001, "Six Habits Of Merely Effective Negotiators", Harvard Business Review, Vol. 79(4), Pp.87-95.

Swaidan, Z. (2007). Culture And Negotiation Ethics. Review Of Business Research, 7(5)

Thomas, K. (1976): Conflict And Conflict Management. In: Dunnette, M. (Ed.): Handbook In Industrial And Organizational Psychology. Chicago.

Thompson, L. L. 2005. The Mind And Heart Of The Negotiator (3rd Ed.).Upper Saddle River, Nj: Pearson/Prentice Hall.

Umeokafor, E. C., (2010). A Review Of Land Information Management In Enugu And Anambra States And The Potentials Of Gis In Improving Land Information Management. Unpublished M.Sc. Dissertation Submitted To Estate Management Department, Nnamdi Azikiwe University, Enugu, Nigeria. Retrieved From Http://Www.Naulibrary.Org/Dglibrary/Admin/Book_Directory/Thesis/10380.Pdf 